УДК 316.627

DOI https://doi.org/10.26661/2310-4368/2021-2-6

\title{
РЕФЛЕКСИВНІСТЬ ЯК ЧИННИК РОЗВИТКУ ЕМОЦІИНОӦ СТІЙКОСТІ ОСОБИСТОСТІ
}

\author{
Малхазов О. P. \\ доктор психологічних наук, професор, \\ головний науковий співробітник лабораторії сочіальної психологї̈ особистості \\ Інститут соціальної та політичної психології \\ Національної академії педагогічних наук України \\ вул. Андрївська, 15, Київ, Украӥна \\ orcid.org/0000-0001-7312-5830 \\ Alexander.malkhazov@gmail.com
}

Ключові слова: суперкластери якостей, рефлексивні профілі, діагностичні маркери, поведінкові прояви.
Стаття присвячена проблемі розвитку емоційної стійкості у соціальнопсихологічному супроводі. Висунуто припущення щодо існування значущих зв'язків між індивідуально-психологічними характеристиками особистості і особливостями подолання нею емоційно несприятливих ситуацій. За результатами емпіричного дослідження виявлено три суперкластери якостей, на основі яких розроблено типологію емоційних профілів особистості та виокремлено шість типів профілів осіб з різним потенціалом розвитку емоційної стійкості. На основі суперкластера рефлексивності виокремлено два типи профілів респондентів: схильні та не схильні до рефлексивності. Встановлено, що у осіб, схильних до рефлексивності, достовірно нижчі показники гіпертимності, комунікабельності та циклотимності, водночас вони більш тривожні, дистимічні, емотивні та збудливі. Емпірично виділено чотири підтипи осіб, схильних до рефлексивності: гіпертимно-домінантні, активноімпульсивні, рефлексивно-тривожні, нейротично-застрягаючі. Для типу профілю з низьким рівнем рефлексивності виділено три підтипи: гіпертимно-імпульсивний, активно-збалансований та емотивнопедантичний. Описано індивідуальні характеристики та особливості поведінкових проявів осіб з високою і низькою рефлексивністю, які варто враховувати у процесі супроводу. Виокремлено діагностичні маркери профілів рефлексивності, які можуть застосовуватись для експрес діагностики. До маркерів профілю осіб, схильних до рефлексії, віднесено такі: прагнення контролю і аргументації; слабкість механізмів психологічного захисту (насамперед витіснення); низька комунікабельність; прояви тривожності і нестабільності у емоційно значущих ситуаціях та тяжіння до правил, ритуалів, традицій і усталених моделей поведінки (як захисний механізм). До діагностичних маркерів типу профілю «не схильних до рефлексивності» віднесено: готовність приймати на віру недостовірну інформацію, якщо вона відповідає очікуванням; відмову від планування своїх дій i прогнозування їх наслідків; імпульсивність і агресивність у просуванні своїх переконань; авантюризм, готовність до ризику. 


\title{
REFLEXIVENESS AS DEVELOPMENT FACTOR OF INDIVIDUAL'S EMOTIONAL RESILIENCE
}

\author{
Malkhazov O. R. \\ Doctor of Psychological Sciences, Professor, \\ Chief Researcher of the laboratory of social psychology of personality \\ Institute of Social and Political Psychology \\ of the National Academy of Pedagogical Sciences of Ukraine \\ Andriivska str., 15, Kyiv, Ukraine \\ orcid.org/0000-0001-7312-5830 \\ Alexander.malkhazov@gmail.com
}

Key words: quality

superclusters, reflexive profiles, diagnostic markers, behavioral manifestations.
The article is dedicated to the problem of emotional resilience development in socio-psychological assistance. The assumption of the existence of significant connections between individual psychological characteristics of an individual and specifics of overcoming emotionally adverse situations was made. According to the results of empirical research, three superclusters of qualities, based on which the typology of emotional profiles of an individual were developed and six types of personas with different potential for the development of emotional resilience were defined. On the basis of a supercluster of reflexiveness, two types of respondents' profiles were defined: those who are prone to reflexiveness and those who are not. It was found that individuals who are prone to reflexiveness have lower indicators of hyperthymic, people skills, and cyclothymic, while being more anxious, dysthymic, emotive, and excitable. Empirically four subtypes of individuals who are prone to reflexiveness: hyperthymic-dominant, active-impulsive, reflexive-anxious, neurotic-stuck. For types with low levels of reflexiveness, three subtypes were defined: hyperthymic-impulsive, active-balanced, and emotive-pedantic. Individual characteristics and specifics of behavioural manifestations of individuals with high and low reflexiveness, which need to be considered in the assistance process, were described. Diagnostic markers of reflexiveness profiles, that can be applied for express diagnostics, were defined. Markers of the profile of individuals who are prone to reflexiveness were defined: the desire of control and argumentation; weakness of mechanisms of psychological protection (foremost, repression); low people skills; manifestations of anxiety and inclination towards rules, rituals, traditions, and established behavioural models (as protective mechanism). Markers of profile of individuals that are "not prone to reflexiveness": readiness to believe in unreliable information, if it meets the expectations; refusal to plan their actions and predict their consequences; impulsiveness and aggressiveness in promotion of their beliefs; adventurism, readiness to risk.
Постановка проблеми. Емоційне напруження в українському суспільстві, спровоковане російською агресією та накопиченням проблем переселенців, комбатантів і членів їх родин, останнім часом поглибилось через пандемію COVID-19. Про негативні тенденції та зниження психологічного здоров’я українців свідчать останні дослідження психологів [1].

У сучасній соціально-психологічній науці накопичено багато емпіричного матеріалу, зібраного у процесі надання допомоги особам, які адаптуються до викликів соціального середовища. Водночас дослідження чинників розвитку емоційної стійкості (ЕC) у соціально-психологічному супроводі осіб, які потребують психологічної допомоги, залишаються поза увагою науковців. Одним із таких чинників, на нашу думку, є здатність клієнта до рефлексивності.

Метою статті $\epsilon$ емпіричне обгрунтування типів рефлексивних профілів особистості та визначення потенціалу рефлексивності для розвитку емоційної стійкості у процесі соціально-психологічного супроводу. 
Виклад основного матеріалу дослідження. Підвищення ефективності соціально-психологічного супроводу розвитку ЕС осіб під час переходу до умов мирного життя можна досягти за рахунок розробки та впровадження індивідуалізованих протоколів, які забезпечують успішність контролю та реалізації адекватних моделей поведінки у процесі взаємодії. В основу нашого дослідження покладено уявлення про те, що виявлення рефлексивного профілю клієнта дасть змогу психологу вибудовувати супровід розвитку емоційної стійкості з урахуванням його потенційних можливостей.

Аналіз досліджень, присвячених контролю емоцій та емоційних станів у роботах зарубіжних $[2 ; 3 ; 4$ та ін.], російських [5;6; 7;8 та ін.] та українських $[9 ; 10 ; 11$ та ін.] авторів, дає підстави припускати існування значущих зв'язків між індивідуально-психологічними характеристиками особистості і особливостями подолання нею емоційно несприятливих ситуацій. Водночас застосування діагностичних процедур, які дають змогу скласти уявлення про індивідуально-психологічні ресурси розвитку ЕС особистості, як то здатності клієнта до антиципації й розрізнення власних емоційних станів, до рефлексії мотивації емоційних проявів та їх впливу на якість життя, особистісні акцентуації тощо в умовах супроводу є доволі складним, а почасти й взагалі не можливим.

Відтак постає завдання пошуку способів експрес діагностики, одним із шляхів вирішення якого, на нашу думку, є встановлення маркерів, які б давали змогу визначити психологічний і психофізіологічний ресурс особи.

Дизайн дослідження, спрямованого на виявлення таких маркерів, передбачав: а) виокремлення особистісних якостей, які зумовлюють розвиток ЕС; б) відбір стандартизованих діагностичних методик для емпіричного дослідження чинників емоційної стійкості; в) статистичну обробку масиву емпіричних даних з метою визначення кластерів якостей, які зумовлюють ЕС особистості; г) виокремлення діагностичних маркерів, за якими можна було б типологізувати клієнтів i прогнозувати їх потенціал розвитку ЕС. На основі аналізу результатів попередніх досліджень $[3 ; 5 ; 6 ; 7 ; 10$ та ін.] ми виокремили 24 особистісні риси, які згадувались науковцями як такі, що тією чи тією мірою пов'язані з ЕС особистості. Для ix діагностування були обрані опитувальники: Я. Стреляу, Л. Терстоуна, К. Леонгарда - Г. Шмишека та Г. Айзенка [12]. Дослідження проводилось на вибірці у 485 осіб віком від 18 до 36 років. Отримані результати оброблялись за допомогою статистичної програми «R» $[13 ; 14]$.

За результатами обробки масиву емпіричних даних було отримано три базові супер-кластери якостей, на основі яких розроблено типологію емоційних профілів особистості та виокремлено шість типів профілів осіб з різним потенціалом розвитку емоційної стійкості. Одним із цих супер-кластерів виявився супер-кластер рефлексивності, відповідно було виокремлено два типи профілів респондентів: схильні та не схильні до рефлексивності. Розглянемо детальніше індивідуальні особливості респондентів, які відносяться до виокремлених типів.

Зауважимо, що виокремити надійні маркери для розпізнавання профілю 3 середніми показниками рефлексивності видається проблематичним. Відтак далі аналізуватимемо типи профілів респондентів з високим + достовірно вищим за середній (B) та низьким + достовірно нижчим за середній $(\mathrm{H})$ рівнями рефлексивності.

Результати порівняльного аналізу цих типів профілів (рис. 1, 2) дають підстави стверджувати, що у осіб з високим рівнем рефлексивності, на відміну від осіб з низьким, достовірно нижчі показники: 16 - гіпертимності $(\mathrm{P}<0,05)$; 10 - комунікабельності та 19 - циклотимності ( $<0,01)$; достовірно вищими виявились показники: 18 - тривожності та 17 - дистимічності; 21 - емотивності та 15 - збудливості $(\mathrm{P}<0,01)$.

На основі аналізу емоційного профілю респондентів, схильних до рефлексивності, 3 високою ймовірністю можна очікувати знижену потребу у комунікації, перепади настрою від активності до пасивності, тривожності та нестабільності поведінки, вразливості, бажання контролювати ситуацію та отримувати аргументовану інформацію, що слід враховувати психологу при плануванні соціально-психологічного супроводу та стимулюванні розвитку емоційної стійкості.

Представлена на рис. 3 факторно-кореляційно-кластерна модель профілю респондентів 3 високим рівнем рефлексивності дала змогу виділити чотири підтипи осіб, схильних до рефлексивності, а саме: гіпертимно- домінантні (С20), активно-імпульсивні (C15), рефлексивно-тривожні (С16), нейротично-застрягаючі (C18).

Перший підтип (C20), позначений нами як гіпертимно-домінантний, характеризується вираженими збудливістю, рухливістю, домінантністю, гіпертимністю при середніх показниках врівноваженості, дистимічності, екстра-інтроверсії.

Відтак у процесі соціально-психологічного супроводу розвитку емоційної стійкості від гіпертимно-домінантних клієнтів варто очікувати:

- високої працездатності та уміння швидко переключатись 3 одного виду діяльності на інший;

- здатності на перших етапах взаємодії з опонентом виявляти витримку та врівноваженість (як захисний механізм); 


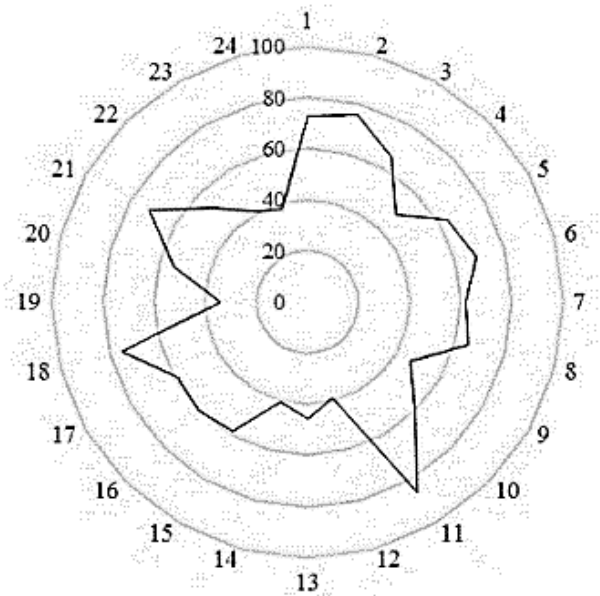

Рис. 1. Психологічний профіль осіб 3 високим рівнем рефлексивності (11)

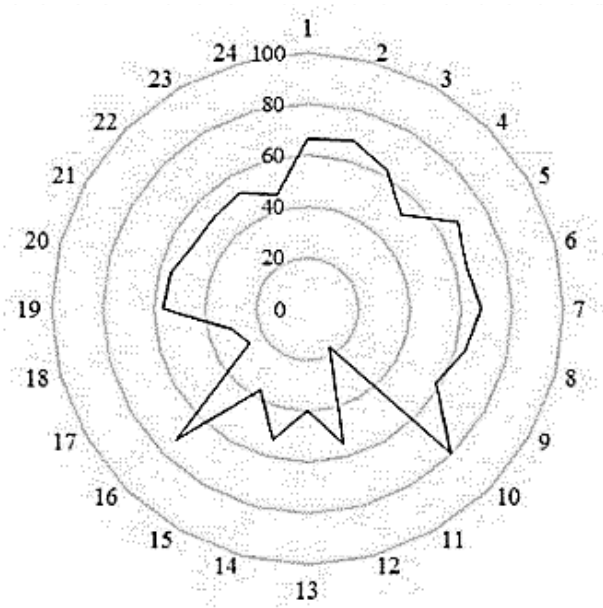

Рис. 2. Психологічний профіль осіб 3 низьким рівнем рефлексивності (11)

Примітка: Коло від 0 до 20 \% відповідає низькому рівню прояву досліджуваного показника (Н); 3 позначкою $20-40 \%$ - значенням нижчим за середнє (НзС); від 40 до 60\% - середньому значенню (Ср.); - $60-80 \%-$ вище за середнє (ВзС), а від 80 - 100\% - високому значенню (В).

Умовні позначення: показники за опитувальниками: Я. Стреляу: 1- сила нервових процесів збудження, 2 - сила нервових процесів гальмування, 3 - рухливість нервових процесі, 4 - баланс нервових процесів за силою збудження; Л. Терстоуна: 5 - активність, 6 - фізична активність, 7 - імпульсивність, 8 - домінантність, 9 - врівноваженість, 10 - комунікабельність, 11- рефлексивність; К. Леонгарда - Г. Шмишека: 12 - демонстративність, 13 - педантичність, 14 - застрягання, 15 - збудливість, 16 - гіпертимність, 17 - дистимічність, 18 - тривожність, 19 - циклотимність, 20 - екзальтованість, 21 - емотивність; Г. Айзенка: 22 - екстраверсія-інтроверсія, 23 - нейротизм, 24 - шкала неправди.

- неспроможності тривалий час зберігати рівновагу та витримку;

- прагнення нав'язувати своє бачення та свої погляди у межах, які дозволяє партнер по взаємодії.

Другому підтипу (С15) названому активно-імпульсивним, властиві висока активність, гальмування та імпульсивність на тлі середніх здатностей до комунікації і правдивості.

У процесі соціально-психологічного супроводу розвитку емоційної стійкості осіб цього підтипу слід очікувати:

- високої працездатності та браку стриманості;

- мінливості настрою та проблем у комунікації;

- відвертості у взаємодії із значущими іншими.

Третій підтип (С16) був названий рефлексивно-тривожнни. Особам 3 таким профілем властиві високі рефлексивність і здатність до фізичної активності, виражені емотивність і тривожність при середній вираженості збудливості і педантизму.

Обираючи заходів соціально-психологічного супроводу розвитку емоційної стійкості для осіб 3 таким підтипом варто враховувати, що вони:

- схильні до самоспостереження, попереднього планування, але не завжди реалізують заплановане; надають перевагу діяльності, яка вимагає м'язових зусиль та значних енергетичних затрат;
- прагнуть дотримуватись правил, ритуалів, традицій та тяжіють до звичних моделей взаємодії (захисний механізм);

- чутливі і вразливі аж до реактивної депресії внаслідок душевних потрясінь.

Для четвертого підтипу (С18) - нейротично-застрягаючого - характерні середні показники застрягання та екзальтованості на тлі низьких демонстративності та нейротизму.

У соціально-психологічному супроводі розвитку емоційної стійкості осіб цього підтипу варто очікувати:

- авантюрних дій у емоційно несприятливих ситуаціях (як захисний механізм) та низької здатності до витіснення негативних спогадів;

- частої зміни гіпертимних і дистимічних станів, при цьому у дистимічній фазі можливі пригніченість та уповільнення мисленнєвих процесів;

- проявів грубості та егоїзму на тлі альтруістичних спонукань (як захисний механізм).

Узагальнюючи аналіз поведінкових проявів респондентів з високою здатністю до рефлексивності можна виокремити діагностичні маркери, за якими психолог може розпізнати осіб 3 цим типом профілю. До таких маркерів відносимо:

- прагнення контролю і аргументації;

- слабкість механізмів психологічного захисту (насамперед витіснення); 


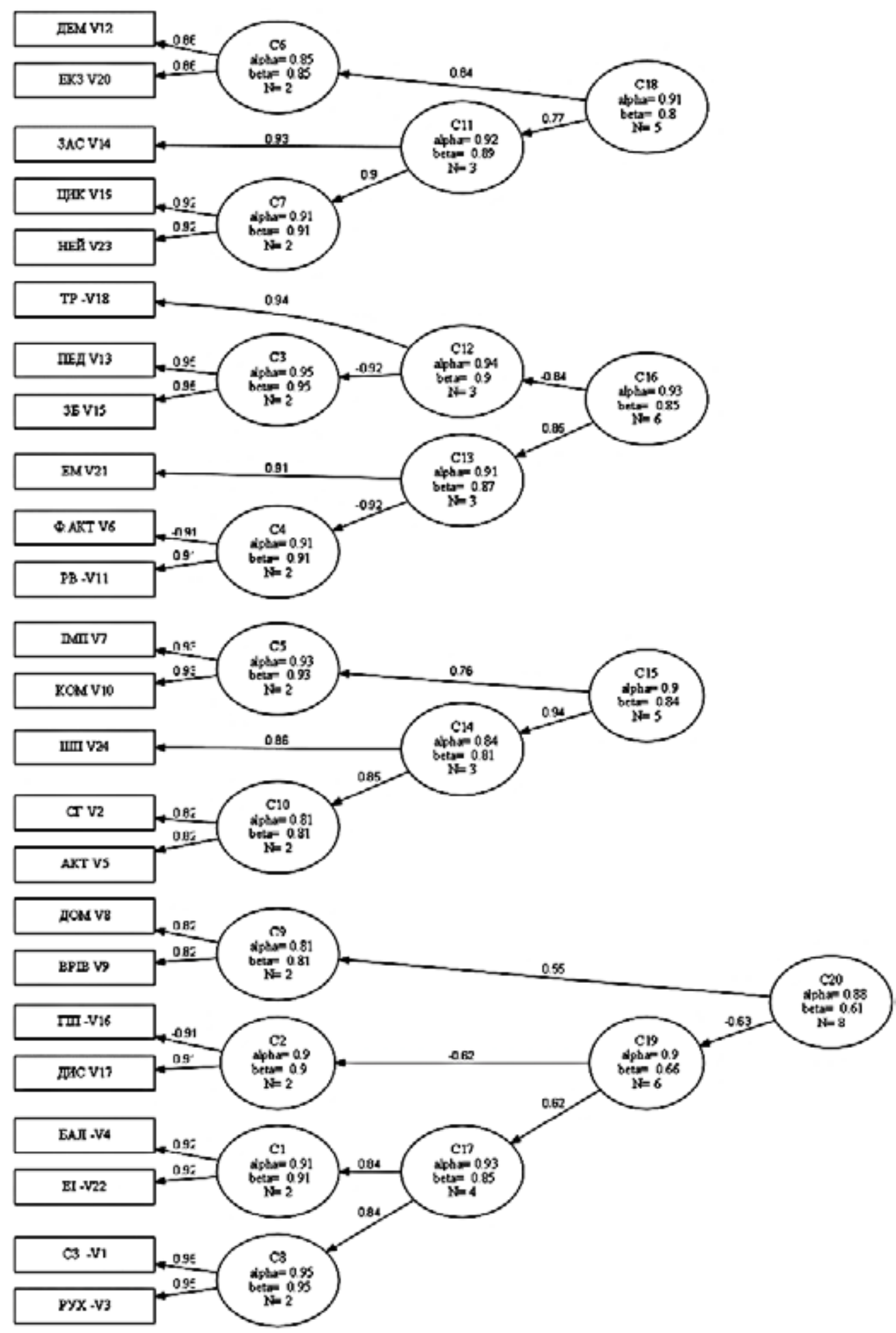

Рис. 3. Факторно-кореляційно-кластерна модель профілю осіб з високим рівнем рефлексивності

Примітка: Факторно-кореляційно-кластерна модель, побудована за методом $\mathrm{R}$ програми $[13 ; 14]$

Умовні позначення: $\mathrm{C} 1$ - C21- номери кластерів; $\alpha$ - коефіцієнт альфа Кронбаха; $\beta$ - коефіцієнт ризику; 0,74 на стрілочках, які, наприклад, ведуть до V7, V8 - коефіцієнти кореляції (r), надійність всіх r на рівні не нижчому за $\mathrm{P}<0,05$; N-загальна кількість рис, які входять до складу відповідного кластеру; опитувальники: Я. Стреляу: V1сила нервових процесів збудження, V2 - сила нервових процесів гальмування, V3 - рухливість нервових процесі, V4 - баланс нервових процесів за силою збудження; Л. Терстоуна: V5 - активність, V6 - фізична активність, V7 - імпульсивність, V8 - домінантність, V9 - врівноваженість, V10 - комунікабельність, V11 - рефлексивність; К. Леонгарда - Г. Шмишека: V12 - демонстративність, V13 - педантичність, V14 - застрягання, V15 - збудливість, V16 - гіпертимність, V17 - дистимічність, V18 - тривожність, V19 - циклотимність, V20 - екзальтованість, V21 - емотивність; Г. Айзенка: V22 - екстраверсія-інтроверсія, V23 - нейротизм, V24 - шкала неправди. 


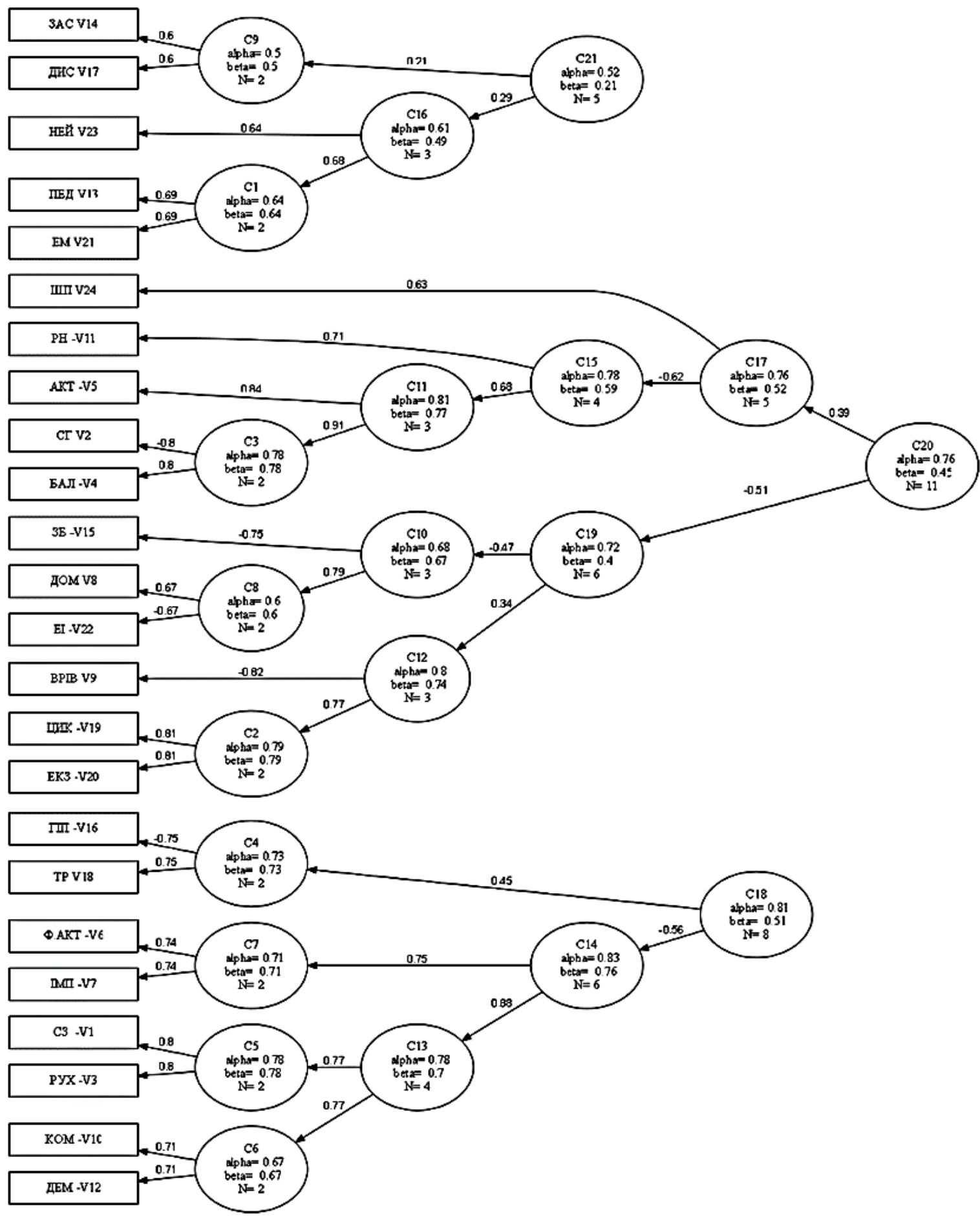

Рис. 4. Факторно-кореляційно-кластерна модель типу профілю осіб 3 низьким рівнем рефлексивності

Примітка: Факторно-кореляційно-кластерна модель побудована за методом R програми [13; 14].

Умовні позначення: $\mathrm{C} 1$ - $\mathrm{C} 21$ - номери кластерів; $\alpha$ - коефіцієнт альфа Кронбаха; $\beta$ - коефіцієнт ризику; 0,74 на стрілочках, які, наприклад, ведуть до V7, V8 - коефіцієнти кореляції (r), надійність всіх r на рівні не нижчому за $\mathrm{P}<0,05$; N-загальна кількість рис, які входять до складу відповідного кластеру; опитувальники: Я. Стреляу: V1 - сила нервових процесів збудження, V2 - сила нервових процесів гальмування, V3 - рухливість нервових процесі, V4 - баланс нервових процесів за силою збудження; Л. Терстоуна: V5 - активність, V6 - фізична активність, V7 - імпульсивність, V8 - домінантність, V9 - врівноваженість, V10 - комунікабельність, V11 - рефлексивність; К. Леонгарда - Г. Шмишека: V12 - демонстративність, V13 - педантичність, V14 - застрягання, V15 - збудливість, V16 - гіпертимність, V17 - дистимічність, V18 - тривожність, V19 - циклотимність, V20 - екзальтованість, V21 - емотивність; Г. Айзенка: V22 - екстраверсія-інтроверсія, V23 - нейротизм, V24 - шкала неправди. 
- низька комунікабельність;

- прояви тривожності і нестабільності у емоційно значущих ситуаціях та тяжіння до правил, ритуалів, традицій і усталених моделей поведінки (як механізм захисту).

На основі отриманої факторно-кореляційно-кластерній моделі типу профілю 3 низьким рівнем рефлексивності (рис. 4) можна виділити три підтипи: гіпертимно-імпульсивний (C18), активно-збалансований (С20) та емотивно-педантичний (С21).

Перший підтип (С18) - гіпертимно-імпульсивний - характеризується вищими за середній рівень показниками комунікабельності, рухливості нервових процесів, сили нервових процесі збудження, імпульсивності, гіпертимності, фізичної активності при середніх показниках демонстративності та низькій тривожності.

Другому підтипу (С20) - активно-збалансованому - властиві: вищий за середній рівень активності, сили нервових процесів гальмування та домінантності; середній рівень врівноваженості, циклотимності, фізичної активності, правдивості, демонстративності та екзальтованості; низький рівень збудливості, рефлексивності, балансу нервових процесів (зміщений у бік сили збудження) та екстраверсії.

Третій підтип (С21) - емотивно- педантичний - вирізняється середніми показниками емотивності, педантичності, нейротизму і застрягання та нижчим за середній рівнем дистимічності.

Узагальнивши викладене можна виокремити характерні поведінкові прояви клієнтів 3 низькою рефлексивністю, які варто враховувати у процесі соціально-психологічного супроводу, зокрема:

- низький рівень здатності до взаємодії, особливо з малознайомими;

- здатність тривалий час протидіяти часто повторюваним зовнішнім подразненням підвищеної сили та швидко переключатись 3 одного виду діяльності на інший;

- імпульсивно-агресивні реакції, дратівливість, нестриманість, перепади настрою, авантюрні дії, прагнення отримувати задоволення від екстремальних ситуацій;

- небажання аналізувати власні вчинки, контролювати їх наслідки;

- прагнення нав'язувати своє бачення, домінування (як захисний механізм для маскування власної невпевненості);

- чутливість до особистих емоційних переживань і вихід за рамки наперед визначених обмежень (як захисний механізм).

До діагностичних маркерів типу профілю «не схильних до рефлексивності» відносимо:

- готовність приймати на віру недостовірну інформацію, якщо вона відповідає очікуванням;

- відмова від планування своїх дій і прогнозування їх наслідків;

- імпульсивність і агресивність у просуванні своїх переконань;

- авантюризм, готовність до ризику.

Висновки.

Підвищення ефективності соціально-психологічного супроводу розвитку ЕС можна досягти за рахунок розробки і впровадження моделей супроводу, орієнтованих на індивідуалізацію протоколів та стратегій. Однією з таких моделей є урахування емоційного профілю клієнта при виборі стратегії розвитку емоційної стійкості особи.

Одним із чинників розвитку емоційної стійкості є особистісний потенціал рефлексивності. Запропонований метод побудови факторно-кореляційно-кластерної моделі за типами профілю рефлексивності дав змогу визначити поведінкові прояви осіб 3 високою і низькою рефлексивністю, які варто враховувати у роботі з клієнтом. Виокремлені діагностичні маркери для осіб $з$ різними профілями рефлексивності стануть у пригоді як інструменти експрес діагностики.

Перспективи подальших досліджень вбачаються нами у розробці та апробації впровадження маркерів різних типів профілів для створення індивідуально орієнтованих протоколів соціально-психологічного супроводу розвитку емоційної стійкості та відбору ефективних стратегії.

\section{ЛІТЕРАТУРА}

1. Матеріали Всеукраїнського науково-практичного семінару “Горизонти посттравматичного особистісного життєтворення”, м. Київ, 2020. https://ispp.org.ua/wp-content/uploads/Static/Horizons_of_ post-traumatic_personal_life-creation.pdf

2. Hay I., Ashman A.F. The development of adolescents' emotional stability and general selfconcept: the interplay of parents, peers, and gender // International journal of disability, development and education. 2003. No. 50 (1). P. 77-91.

3. Craik K.H. Personality research methods: An historical perspective // Journal of personality. - 2007. № 54. - P. 18-51.

4. Wong P.T.P. The resource-congruence model of coping and the development of the Coping Schema Inventory. / P.T.P. Wong, G.T. Reker, E. Peacock // Handbook of Multicultural perspectives on stress and coping / Ed. by P. T.P. Wong, L.C.J. Wong. - New York, NY : Springer, 2006. - P. 223-283. 
5. Аболин Л.М. Психологические механизмы эмоциональной устойчивости человека. Изд-во Казанского университета, 1987. $262 \mathrm{c.}$

6. Бодров В.А. Личностная детерминация развития и преодоления психологического стресса / Совладающее поведение: Современное состояние и перспективы / Под ред. А. Л. Журавлева, Т. Л. Крюковой, Е. А. Сергиенко. - М.: Изд-во «Институт психологии РАН», 2008. С. 235-256.

7. Дементьева И.М. Личностные детерминанты психологической устойчивости у спортсменов высокой квалификации, занимающихся регби-7. Актуальные вопросы физической культуры и спорта. ФГБОУ ВО «Кубанский государственный университет физической культуры, спорта и туризма». Краснодар 2019. Том: 21. С. 85-92.

8. Широкоступова А.О. Эмоциональная устойчивость как психологический феномен. Психология. Историко-критические обзоры и современные исследования. 2016. № 4. С. 45-52.

9. Аршава І.Ф. Психічні стани як форми концентрованого прояву емоційної стійкості й емоційної вразливості. Медицинская психология № 3' 2012 г. С. 3-11.

10. Малхазов О. Р. Чинники нейротизму і тривожності особистості в соціально-психологічному супроводі розвитку емоційної стійкості Зб. наук. статей ПЗВО «Київський міжнародний університет» й Інституту соціальної та політичної психології НАПН України. Серія: «Психологічні науки: проблеми і здобутки». Вип. (1-2) 13-14. К. КиМУ, 2019. - С. 274-297. https://kymu.edu.ua/upload/pdf files/zbirnyk_zmist_13.pdf

11. Рева О.М. Емоційна стійкість в контексті подолання професійного стресу працівників правоохоронних органів. Зб. мат. круглого столу: Психологічні засади забезпечення службової діяльності працівників правоохоронних органів : матеріали круглого столу (в авторській редакції) - Кривий Ріг, 2017. - C. 204-207.

12. Кокун О.М., Пішко І.О., Лозінська Р.С., Копаниця О.В., Малхазов О.Р. Збірник методик для діагностики психологічної готовності військовослужбовців військової служби за контрактом до діяльності у складі миротворчих підрозділів: Метод. посібник. - К.:НДЦ ГП ЗСУ, 2011. - $281 \mathrm{c.}$

13. Revelle, W. Hierarchical Cluster Analysis and the Internal Structure of Tests. Multivariate Behavioral Research, 1979, 14, 57-74.

14. Revelle, W. and Zinbarg, R. E. Coefficients alpha, beta, omega and the glb: comments on Sijtsma. Psychometrika, 2009.

\section{REFERENCES}

1. Materialy Vseukrainskoho naukovo-praktychnoho seminaru "Horyzonty posttravmatychnoho osobystisnoho zhyttietvorennia” (2020). https://ispp.org.ua/wp-content/uploads/Static/Horizons_of_posttraumatic_personal_life-creation.pdf. [in Ukrainian].

2. Hay, I., \& Ashman, A. F. (2003). The development of adolescents' emotional stability and general selfconcept: The interplay of parents, peers, and gender. International journal of disability, development and education, 50(1), 77-91.

3. Craik, K.H. (1986). Personality research methods: An historical perspective. Journal of Personality, 54(1), 18-51.

4. Wong, P. T., Reker, G. T., \& Peacock, E. J. (2006). A resource-congruence model of coping and the development of the coping schema inventory.

5. Abolin L.M. (1987). Psihologicheskie mehanizmyi emotsionalnoy ustoychivosti cheloveka [Psychological mechanisms of human emotional stability]. Izd-vo Kazanskogo universiteta. [in Russian].

6. Bodrov V.A. (2008), Lichnostnaya determinatsiya razvitiya i preodoleniya psihologicheskogo stressa [Personal determination of development and overcoming psychological stress]. In Sovladayushcheye povedeniye. Sovremennoye sostoyaniye i perspektivy] / Pod red. A. L. Zhuravleva, T. L. Kryukovoy, E. A. Sergienko. - M.: Izd-vo «Institut psihologii RAN», S. 235-256. [in Russian].

7. Dementeva I.M. (2019). Lichnostnyie determinantyi psihologicheskoy ustoychivosti u sportsmenov vyisokoy kvalifikatsii, zanimayuschihsya regbi-7. [Personal determinants of psychological stability in highly qualified athletes involved in rugby-7]. Aktualnyie voprosyi fizicheskoy kulturyi i sporta. FGBOU VO «Kubanskiy gosudarstvennyiy universitet fizicheskoy kulturyi, sporta i turizma». Krasnodar. Tom: 21. S. 85-92. [in Russian].

8. Shirokostupova A.O. (2016). Emotsionalnaya ustoychivost kak psihologicheskiy fenomen. [Emotional stability as a psychological phenomenon]. Istoriko-kriticheskie obzoryi i sovremennyie issledovaniya. Psihologiya (21). S. 45-52. [in Russian].

9. Arshava I.F. (2012). Psykhichni stany yak formy kontsentrovanoho proiavu emotsiinoi stiikosti y emotsiinoi vrazlyvosti. [Mental states as forms of concentrated manifestation of emotional stability and emotional vulnerability]. Medytsynskaia psykholohyia № 3 2012h. S. 3-11. [in Ukrainian]. 
10. Malkhazov O.R. (2019). Chynnyky neirotyzmu i tryvozhnosti osobystosti v sotsialno-psykholohichnomu suprovodi rozvytku emotsiinoi stiikosti [The Causes of Neuroticism and Anxiety of an Individual in Social Psychological Assistance of the Development of Emotional Resilience]. Zb. nauk. statei PZVO «Kyivskyi mizhnarodnyi universytet» y Instytutu sotsialnoi ta politychnoi psykholohii NAPN Ukrainy. Seriia: «Psykholohichni nauky: problemy i zdobutky». Vyp. (1-2) 13-14. K. KyMU. - S. 274-297. https:// kymu.edu.ua/upload/pdf_files/zbirnyk_zmist_13.pdf [in Ukrainian].

11. Reva O.M. (2017). Emotsiina stiikist $v-k o n t e k s t i$ podolannia profesiinoho stresu pratsivnykiv pravookhoronnykh orhaniv. [Emotional resilience in the context of overcoming the professional stress of law enforcement officers]. Zb. mat. kruhloho stolu: Psykholohichni zasady zabezpechennia sluzhbovoi diialnosti pratsivnykiv pravookhoronnykh orhaniv : materialy kruhloho stolu (v avtorskii redaktsii) Kryvyi Rih. S. 204-207. [in Ukrainian].

12. Kokun O.M., Pishko I.O., Lozinska R.S., Kopanytsia O.V., Malkhazov O.R. (2011). Zbirnyk metodyk dlia diahnostyky psykholohichnoi hotovnosti viis-kovosluzhbovtsiv viiskovoi sluzhby za kontraktom do diialnosti u skladi myro-tvorchykh pidrozdiliv: Metodychnyi posibnyk [Collection of methods for diagnosing the psychological readiness of military servicemen under contract to work as part of peacekeeping units: Methodical manual]. - K.: NDTs HP ZSU. [in Ukrainian].

13. Revelle, W. (1979). Hierarchical Cluster Analysis and the Internal Structure of Tests. Multivariate Behavioral Research, 14, 57-74.

14. Revelle, W. and Zinbarg, R. E. (2009) Coefficients alpha, beta, omega and the glb: comments on Sijtsma. Psychometrika. 